\title{
Breaking-Away from the Comfort Zones: Postmodernism in Selected Philippine Contemporary Novels in English
}

\author{
Diana Joy L. Basada \\ Central Luzon State University, Philippines \\ diana_basada@yahoo.com \\ Mark Anthony G. Moyano \\ Central Luzon State University, Philippines \\ markanthonymoyano@clsu.edu.ph
}

DOI: http://doi.org/ 10.36892/ijlls.v3i1.468

\begin{tabular}{ll} 
Received: & Abstract \\
14/01/2021 & The paper tries to prove the existence of postmodernism in selected Philippine \\
\hline Accepted: & contemporary novels, namely: Salamanca (2017), Leche (2011), and \\
04/03/2021 & Naermyth (2010), by identifying the postmodern characteristics embedded in \\
\hline Keywords: & them. It also discusses the association of the identified characteristics of \\
literary & postmodernism with the overall meaning of the novels. After the analysis, this \\
postmodernism, & study yields the following major findings: the characteristics of \\
postmodern & postmodernism are identified in the selected Philippine contemporary novels \\
characteristics, & in English; these include pastiche, intertextuality, the celebration of little \\
contemporary & narratives, the technique of using nonlinear narratives, parody, irony, the \\
literature, Philippine & question of identity, the issue of subjectivity, and magic realism. Furthermore, \\
contemporary & it is proven that the postmodern characteristics help each of the novels to \\
novels. & achieve their overall meanings through contributing to the development of \\
& their themes.
\end{tabular}

\section{INTRODUCTION}

In the landscape of international literary studies, postmodernism has received massive critical attention as being the subject of endless discussions and debates because of its radical and experimental character. However, only a few studies about postmodernism have been conducted in the Philippine literary scene. This draws the current researcher to the assumption about the existence of postmodern concepts in the country after reading foreign researches about the attribution of postmodernism in Philippine novels such as Dogeaters (1990) and Ilustrado (2010) which are both published internationally.

This study presents the characteristics of postmodernism as seen in the contemporary horizon of Philippine novels and its relationship to the novel's attributed meaning.

\section{METHOD}

This research made use of qualitative, descriptive, and analytical research designs in discussing its findings aided by Niall Lucy's discussion of postmodernism in his book Postmodern Literary Theory: An Introduction (1997).

\section{RESULTS AND DISCUSSION}

The symbolic shift from modernism to postmodernism can be traced back to 1972 when a collage city was built out of the dynamited housing project. It consists of "ornamented tower blocks, imitation medieval squares, and fishing villages, custom-designed 
vernacular houses, renovated factories and warehouses, and rehabilitated landscapes of all kinds as satisfying urban environment" (Montealegre, 2008). It is a good example of social transformation and cultural change - a highly pluralistic mixture and an abstract reason that leads to questioning the modernist ideas and sentiments in various disciplines including literature. For the postmodernist, the question now is "What was literature?", not "What is literature?" to show how the old writings have been produced the new (Arriola, 2006).

These new breeds of literature are already surfaced in the Philippine literary landscape after examining the Philippine contemporary novels understudy in the context of postmodernism. Hence, the characteristics that they have are discussed in the succeeding paragraphs.

\section{Pastiche}

Postmodernism blurs the line that distinguishes high literature from low literature (high art from low art) by incorporating the old and the new (Jameson, 1991). The old refers to the styles that have been invented and the new refers to any combination of the old styles to produce something unique.

One characteristic of postmodernism is pastiche or the result of incorporating the old styles to the contemporary texts. It perhaps can also be understood as the mixture of different strange elements that seemingly do not fit. Pastiche can be noticed most commonly through the mixing of different literary genres to create a "unique" narrative but it can also involve a lot of things. As Chaudhary and Sharma (2011) discussed how Thomas Pynchon incorporated pastiche in his novels through the use of detective, science, and war fictions, songs, pop culture references, real contemporary and historical figures, and fictional history, culture, and concepts.

In Salamanca (2017), the incorporation of pastiche is seen in the structure of the novel by incorporating different styles along with the narrative, and the symbolic mode of representation of the objects depicted by magic realism.

In the structure of the novel, the readers will notice the inclusions of the excerpts from some literary pieces written by Gaudencio - the protagonist of the story who is an awardwinning author in the Philippine literary landscape - in prose and sometimes in verse. Aside from this, there is a series of letters from Intang (Jacinta) written in italicized script text.

The presence of the fictional excerpts including the letters from Intang which also contained a small story in the novel is a compositional technique of the writer to create an intertextual collage of fragmented stories. It is also aided by employing a nonlinear narrative technique to further highlight the quality of fragmentation among the collection of small stories in the text.

Upon looking at the flow of the narrative, something unusual will be noticed among the objects that appeared from the story. One of them is the house of Jacinta Cordova transformed into glass.

The house of Jacinta Cordova became famous in Tagbaoran but for some people like Mrs. Helen Brown, it is just a story created by the townspeople because the story of how the glasshouse created or appeared in their town seems difficult to believe. Also, because most people will not be able to see the house personally. The circulation of Jacinta's story resulted in terrified people who do not want to come near her. They treated her existence as a curse especially the beauty that she had because of this, the people of Tagbaoran refused to have children after her twelfth birthday. Another is the eighteen-day storm that caused the fourteen-day flood. The storm caused the flight of Jacinta Cordova, Mrs. Helen Brown, and Cesar Abalos along with the flood together with strange things floating in the water. 
The storm also took away the famous glass house of Jacinta together with her aunt, Apolinaria Vergara. Jacinta believed that God finally came to get her aunt together with her house after reciting all of her (Apolinaria) endless cycles of prayers.

This strangeness in narrative highlights the association with the concept of magic realism. It is another postmodern feature characterized by portraying imaginary and fantastic objects or events as ordinary in the context of the narrative. This kind of representation is clearly pastiche - mixing the fictional real and the actual real (Baudrillard, 1994).

Another evidence of pastiche in the narrative is the use of the concept of "love at first sight". In the novel, Gaudencio fell in love with Jacinta the moment their eyes met. Other characters in the story also experienced the same thing towards Jacinta including Mrs. Helen Brown and Cesar Abalos.

Love at first sight is a common theme often used by William Shakespeare in his plays especially in Romeo and Juliet and A Midsummer Night's Dream. This concept is also present in classical texts. One example of it is the story of Paris and Helen in Homer's The Iliad, when Paris experienced love upon seeing Helen. This event was drawn to a war between the Trojans and the Greeks, more commonly known as "The Trojan War".

Another example of classical texts with this theme is the story of Cupid and Psyche by Apuleius. In the story, Psyche's beauty was adored by the people more than the beauty of the goddess Venus. As a result, Venus asked her son to use his power over Psyche so that Psyche would fall in love with the most despicable guy on Earth but Cupid, "as he looked upon her, it was as if he shot one of his arrows into his own heart" (Hamilton, 1942, p. 97). In that case, Cupid also experienced the so-called love at first sight.

The recycling of plots and concepts (like the use of love at first sight as a theme in different stories) is also one of the qualities of pastiche. It basically highlights the postmodern view that nothing is new in the contemporary world (Lucy, 1997).

Moreover, Leche's (2011) opening consists of an excerpt from a fictional book entitled Decolonization for Beginners: A Filipino Glossary by fictional author and professor, Bonifacio Dumpit, before the narration of the story started.

What is Decolonization for Beginners: A Filipino Glossary doing in a novel? It was subjected to a combination of an element pasted to prose to create an intertextual collage. The excerpts from this fictional glossary contain the definition and meaning of a highlighted Filipino word that is being utilized in the novel. It usually appears before the word was used in the narrative. The glossary serves as a guide to understand the context of the event happening in the story. Although the glossary is fictional, it serves as a reference for the reader to understand what $\mathrm{s}$ /he was reading. Through this, the author is actually making the readers "participate in the production of significations and meaning" (Montealegre, 2009, p.7).

Aside from the glossary, a list of Tourist Tips also appeared in the book. Just like the glossary, it also serves as a guide in reading the text. At an initial reading, one will identify that the list is solely for Vince to help him in his journey back to the Philippines but actually, it is also for the readers. The author is actually taking the readers to the corners of the Philippines, making them familiar with the place, the culture, as well as the history of the country as postmodernism made the readers participate in the production of truth along with the author and the culture (Lucy, 1997).

The novel also uses flashbacks, nonlinear narrative timelines, parody, and irony. These are some of the literary techniques that are often used by many writers even before postmodernism. The use of these devices highlights the postmodern view that writers can never invent a new kind of writing because styles have already been invented. So, what they are doing now is to combine different writing techniques to produce something unique (Jameson, 1991). The use of flashbacks and nonlinear narrative timelines can be traced back 
to the ancient period where the epics such as Iliad and Mahabharata utilize these narrative techniques. The incorporation of these old literary techniques in the contemporary novel, Leche (2011), is another evidence of Pastiche.

Pastiche is also seen in Leche (2011) through the incorporation of cultural and historical references. One of it is the inclusion of Kris Aquino in the narrative. In the novel, she was described as the "youngest daughter of President Corazon Aquino and the late Senator Benigno "Ninoy" Aquino, whose assassination in 1983 precipitated the downfall of the Marcos dynasty" (Linmark, 2011, p. 27). This is an actual historical fact in the Philippines. The characterization of Kris in the novel is also the same as who she is in the real world. She is a host and an actress who stars in horror movies.

Vince got a chance to meet Kris during his stay in the Philippines. He escorted her to a Santacruzan event in Malate, Manila, and also appeared on her talk show entitled PM Talking with Yours Truly. The talk show was narrated through an interview transcript to clearly depict the conversation. What was written there is the actual conversation of the show that aired on national television. Through this, the novel highlighted how the postmodernist erases the boundaries between fiction and reality by portraying an actual person in a fictional world.

The same findings are seen in the discussion of Sedehi (2013) in the short story by Bahram Sadeghi, "The Man who Does not Return". He wrote that the story destroys the boundaries of fiction and reality by making the narrator confess that the story is purely fiction and nothing is real. However it does not utilize the use of pastiche, instead, the author employs another mode of postmodern representation which is the use of an unreliable narrator.

Another evidence of pastiche in the novel is the involvement of Philippine history including the Spanish-American War, World War I, World War II, and Martial Law through Vince's recollection of his grandfather telling him stories when he was a child who is still living in the Philippines. By including this, the author mixes historical accounts into a diaspora story. A diaspora story is a kind of narrative in which the main character lives or lived outside his homeland. Leche (2011) is considered a diaspora story because it tells the story of how the main character, Vince, lived outside his homeland and returned to it after thirteen years of living in Hawaii, not to mention how the author splits his time between Manila and Honolulu, Hawaii, making him connected with his fictional character.

Before Vince and his siblings migrated to Hawaii, their parents went there as Overseas Filipino Workers (OFW). This story's plot is similar to the actual history of Filipino immigrants in Hawaii. It was during the 20th century when Filipinos started to migrate to Hawaii after the Hawaii Sugar Planters' Association (HSPA) recruited Filipino workers to work with them (Aquino \& Magdalena, n.d.). Most of the Filipino workers choose to settle in Hawaii. Instead of coming back to live in the Philippines, they will just petition their family to live with them in Hawaii, and because of this setup, the Filipino community in Hawaii is continuously growing until today.

The appearance of non-traditional elements of the novel continues to occupy its pages as the story progresses. In addition to the employment of pastiche, Linmark also includes other elements in the narrative like vintage postcards, song lyrics entitled We Won't Go Back to Subic Anymore, and the Signs of the Times.

The vintage postcards were brought by Vince in a bookstore called National Bookworm. He used it to write his messages about his journey in the Philippines to his family in Hawaii. The pictures in the postcards are actually taken from Jonathan Best's $A$ Philippine Album (1998), a book of vintage photograph collection published by Bookmark Inc., borrowed and mixed within the novel. 
The author made use of many references pasted together to create the world inside Leche (2011). If a reader is not exposed to these references, $\mathrm{s} /$ he will not be able to recognize the existence of pastiche in the text. However, those who are aware of these things will have a "deeper enjoyment, and possibly feel rather smart" (Montealegre, 2008, p. 7).

In Naermyth (2010), the novel's setting is post-apocalyptic, five years after the Naermyths waged war against human beings. The setting depicts how these creatures in every myth turned out to be true as they were haunting and torturing human beings. Some of them are the dwende, aswang, pasatsat, and tikbalang.

Aside from these evil creatures, there are also good Naermyths like the diwatas. In the beginning, they did not involve themselves in the clash between the other Naermyths and the human race and they did not consider themselves either an enemy or an ally. It is only Maria Makiling who broke this unwritten rule.

Maria Makiling is the famous diwata of Mount Makiling in Laguna. Her house is a perfect example of a pastiche in the novel. In the legend, Maria Makiling lives in a humble hut or what the Filipinos called kubo but in the novel, it was a big wooden mansion. It was revealed when the group of Athena arrived at the foot of the mountain.

Maria Makiling is not even called by her name. Arao, her assistant diwata who is twohundred and seven years old, informed Athena's group that Maria Makiling hates to be called that because it is too old fashioned. Instead, she wants to be called "Macky". She even calls her cousin, Maria Sinukuan, "Sookie" and branded her as the "old fashioned and uptight" (Francisco, 2010, p. 249). If the group was mesmerized by the appearance of the big wooden mansion outside, it was doubled when they entered the door revealing the breathtaking interior design and furniture of the house.

It is so unusual to see such a wonderful house amid the chaos brought by the Naermyths causing the world to crumble. All that you can see in their community are the fallen buildings, destructed spaces, and desolated plains. When Rowan exclaimed that the house is nice, Arao told them that they brought in a designer from Italy just to make the house that grand. Through the structure of Macky's house, it was clearly shown how the old was combined with the new to create a unique output.

In addition to the frames of intertextual pastiche is the unusual clothing of the other diwatas in Macky's house. They are wearing human clothes as stated in the novel. Another thing is the peculiar explanation of the truth behind the stories about Maria Makiling. One of it is that humans were not allowed inside her house. Arao said that it is not true and they "[...] just don't want humans poking around 'coz [they've] been stealing cable for years. And [they've] been avoiding the Bureau of Internal Revenue. [They] owe the government trillions of pesos in back taxes" (Francisco, 2010, p. 251). The whole mansion is composed of foreign objects in the sense that these are out of place in the wooden house located at the foot of a mountain especially during the time of destruction. Aside from the interior design of Maria Makiling's house, there is also a hospital room inside where one of Athena's brothers, who got missing during his recent mission, is recovering from his wounds due to the attack that he had received.

One can also see the incorporation of pastiche in the novel's structure by noticing the inclusion of written letters, one from Benevidez and another from River, and a summary of a typewritten laboratory report found in the old house of the Dizon's where Athena lived before the war broke.

\section{Intertextuality}

Since postmodernism celebrates pastiche or the combination of different styles, techniques, genres, and elements, the pluralistic representation of postmodernism was being highlighted. Another characteristic that highlights the same thing is the concept of 
intertextuality. It is defined as the relationship of one text to another, the inclusion of influences, borrowings, a habit of allusiveness, references, and parodies in fiction (Arriola, 2006). A novel, for example, was being used as "a reference or parallel to another literary work, an extended discussion of a work, or adoption of a style" (Chaudhary \& Sharma, 2011, p. 194).

The story of the Naermyths will not be possible if it was not associated with the Filipino myths, legends, and folk tales. This book is a good example of a postmodern feature claiming that a literary work is not a closed system that does not have an outside reference. The intertextual frame of Naermyth (2010) makes the novel unique and different from other texts. The incorporation of the Filipino mythical stories and legends in the novel making it an account for historical facts highlights the intertextual feature of the novel.

The common stories about the dwende (dwarfs) or the nuno sa punso, aswang, pasatsat, and tikbalang are included in the narrative and portrayed as part of the characters' reality.

The stories of the aforementioned creatures used in Naermyth (2010) universe are actually taken from Maximo Ramos' compilation of Philippine Mythology entitled Creatures of Philippine Lower Mythology (1971). The author incorporates the stories of these creatures from the book to complete the characterization of the Naermyths.

The story of $d w e n d e$ is very common to the Filipinos. If someone will see a mound, they will eventually conclude that it is a house of the $d w e n d e$ especially in rural areas of the country. The dwarfs in the Philippines are the smallest mythological creature but they are also the hardest to kill because they are difficult to find (Francisco, 2010).

In myths, aswang pertains to a monster that eats human flesh and blood, most especially children, infants, and unborn fetuses. These creatures also eat human internal organs. They believed that the internal organs of younger humans nourish them for a long time because of their freshness. The myth says that one will identify when the aswang is in human form if the reflection of oneself in their eyes is inverted.

Although aswang is presented in the text with that characterization, there are countless numbers of myths regarding that creature. There are aswang that transform themselves from the human figure into a dog. Thus, it is derived from the term asu-asuhan (aso is a Filipino term for a dog, and asu-asuhan can be translated into a dog-like creature). There are also aswang who use magic to harm their foe. Others steal and eat human corpses and do not want to get involved with the affairs of the living.

Moreover, the story about kapre is also included in the novel. It is characterized as a cigar-smoking giant that will make you forget things like your destination. When a man came across kapre, he will find himself traveling in circles.

Another creature in Philippine mythology that is included in the intertextual frame of Naermyth (2010) is the pasatsat. This creature is characterized as a ghoul wrapped in mats. The myth says that they are the victims of the 2nd World War that are buried in rolled mats. Their spirits are haunted because they never had a proper burial.

The tikbalang is also present in the novel. It is characterized as a creature with a body of a human and a head of a horse but in the latter part of the novel, Athena says that the tikbalang does not exist in the Philippines, but Tito Bing explains that the term tikbalang is the native Filipino term for Wing Wights which is the highest form of Naermyths. These stories are drawn to the connection of Philippine mythology to other mythologies of the world. The author of the novel also mentions some of the mythological characters in connection to the Wing Wights. These include Garuda of the Hindu and Buddhist which is a half-bird, half-man creature; Quetzal of the Aztec and Mayan which is the god of the air; Ra of the Egyptians which is a part falcon; and the Japanese tengu which were known to have beaks and avian characteristics. 
There are also other foreign creatures like dragons and centaurs present in the novel. These creatures made the intertextual frame of Naermyth (2010) much bigger. Even the existence of the kind of angel called Nephilim can be read in the story, taking into account the book of Enoch which is very controversial that it was not included in the Bible.

Aside from these creatures, the existence of diwatas is also included in the novel specifically the fragmented story of Maria Makiling. Also, the author made use of Maria Sinukuan's legend as one of the references to complete the story.

\section{Little Narratives}

In connection with the intertextual frame of the literary works, another postmodern feature which highlights the plurality of postmodernism is the celebration of little narrative as opposed to the modernist's celebration of metanarratives. According to Lucy (1997), there is no correct reading of texts, only a plurality of readings. These little narratives gave birth to the pluralistic interpretation of text wherein its intention is not to unify things with totality. Lyotard's sentiment in The Postmodern Condition, "little is better than big [...] because they are so unhindered by rules and contexts and therefore so open to many indefinite interconnections, are superior to supposedly totalizing macro-forms" (Lucy, 1997, p. 69).

Looking at Salamanca's (2017) narrative structure, it was divided into three parts. These parts can perhaps be considered as the novel's chapters but these are more complicated than that because each of these parts was also divided into smaller parts.

The first part of the narrative has the title, "Gaudencio and Jacinta". It basically tells the bizarre encounter of the two main characters, Gaudencio Rivera and Jacinta Cordova, in the small town of Tagbaoran in Palawan. It was in their first encounter that they fell in love, upon looking at each other's eyes. Gaudencio spends his time writing stories for Jacinta and then he will paste it to the glass walls of Jacinta's house. It is Jacinta's routine to remove every page of Gaudencio's prose every morning. Through this, their love sprang and grew until the storm came to their town leaving Gaudencio on the list of missing people after the rain subdued. When Gaudencio was finally found, they decided to get married. It is still in this part when Gaudencio left Jacinta to return to where he came from. He ran off with Cesar Abalos to live in Manila after eleven days of living with Jacinta.

The second part of the story has the title, "Men, Women, and Other Assorted Fictions". This part of the novel, from the title itself, contains assorted stories about the people who came to live in Tagbaoran and the local people inhabiting the area as well as the stories of Gaudencio and Cesar upon living in Manila. The opening of this part was the story about how Gaudencio left Jacinta for another man. It was a hot topic of the people in Tagbaoran in the succeeding days.

The small stories about the people living in Tagbaoran were also narrated in this part of the novel. This includes the story of Carlito Abalos' resurrection after death when he jumped to embrace the sea; the story of Mrs. Helen Brown, a foreign missionary who came to be the town's teacher; the story of Bau Long Hyun's journey of crossing the sea from his hometown in Vietnam; and the story about Shiro, the three-legged dog who lost his master in the storm.

Aside from these, Gaudencio's ascent to the literary scene in Manila was narrated in this novel's part. He bragged many awards including the Carlos Palanca Memorial Awards for Literature, the highest literary award in the country. His relationship with Cesar ended during the peak of his success. Cesar went back to Tagbaoran and Gaudencio has continued writing fueled by lust from the different people whom he slept with. This part was ended when Gaudencio returned to Palawan from Louisiana asking Jacinta to be the mother of his child. 
Finally, the last part was entitled "Letters from Intang". It was composed of stories after Gaudencio's controversial return to Palawan, requesting Jacinta to carry his child. Gaudencio just wanted to have a child with Jacinta and after it, she may leave him and return to Bau Long Hyun in Tagbaoran whom she fell in love with during the absence of Gaudencio. This part was basically the story of how they dwell in the corners of Manila. First, they lived with Gaudencio's family with a massive number of household members. After Jacinta gave birth to their first child, she wanted to stay for a little while for his son and Gaudencio did not object. Soon after, Jacinta requested Gaudencio that they must live outside the roof of Rivera's clan so they rented a small house from Gaudencio's savings. Jacinta was too occupied with being a mother. She gives birth to another child, but this child, unfortunately, died in an accident. Lastly, they bought their own house where Jacinta spent most of her time in their garden. Along with these stories are letters written by Intang (Jacinta) telling her way of life with Gaudencio in Manila to Mina (Filomena), her good friend in Tagbaoran.

The text depicted a collection of narratives within a novel. These three parts of the narrative served as a division within the three timelines of the novel. Each timeline consists of a collection of small stories about different people. Some of these stories had no connection within the main narrative which is about the two main characters. These stories can be considered as a depiction of multiple voices inside a single narrative.

Furthermore, the structure of Leche (2011) is composed of nine books. Each book has small stories divided by their respective titles. Some of these small stories were divided by another header depicting smaller stories. Every book has no specific time frame because it always shifts from one time to another employing the technique of nonlinear narrative.

Generally speaking, the novel is about Vince's journey in the Philippines associated with his memories in his birthplace as well as a glimpse of his life in Hawaii. Although Vince is the main character of the novel, the stories inside it are not solely his. There are stories from the past that belongs to his grandfather as well as to his great grandfather. These stories were narrated through Vince's memory of his grandfather telling stories to his younger self.

There are also little stories about the people whom he encountered in his journey. One of it is the story of Esther, the balikbayan whom he conversed with within the plane. They asked each other some questions and exchanged some information as well but the story of Esther was clearly shown in a one-page narrative. This short narrative was narrated by Esther herself, the point of view of the story was shifted from the third person to first person utilizing postmodernism's stylistic multiplicity through double-voicing (Arriola, 2006).

Although this style-double-voicing and multiple-voicing-is under pastiche as a combination of different styles, it was not discussed earlier under pastiche because it only occurred once in the text. The narrative does not highlight the technique thus the story was entirely narrated in the third person point of view except for this one.

In connection to that, Neziri (2013) emphasizes in his research that postmodernism celebrates the multiplication of voices to disrupt the idea of grand narratives. Hence, it can also be discussed under the concept of little narratives aside from pastiche.

Another narrative from a person encountered by Vince along his way is the story of Sister Marie, a Catholic nun who "defiantly marched head-on against an army tank during the EDSA Revolution" (Linmark, 2011, p. 99). She is an advocate of women's and gay rights and become controversial during that time because her belief is somewhat contradicting the Catholic Church. She became a showbiz personality who starred in films about her life and was featured in many documentaries.

In addition to the collection of Leche's (2011) small narratives is the story of Lilibeth. It was told by her aunt Lita to Vince during the time that she was looking for Leche - an old church that turned into a museum and bar. Due to the heavy traffic caused by a wake that 


\section{English}

blocks the road, Vince gets out of his taxi. This is where Lita approached him upon mistaking him to be the deceased pen pal of Lilibeth and started to tell the story of how they exchanged letters. Finally, the story of Jonas who is Vince's tour guide during his Fort Santiago visit is included in the collection of the novel's little narrative. After his tour, they had a dinner accompanied by a meaningful conversation. Jonas is a queer, he has a degree in history, and he is working as a tour guide aside from taking care of his mother in the hospital. He is traveling every day from Bulacan to Manila just to work. Vince asked him about Leche and they both agreed to go to the place but Jonas did not show up after their dinner.

Leche (2011) is a collection of stories including Vince's life in Hawaii; recollections of him during his childhood days; the life of his grandfather during the war; his journey through the endless streets in Manila that were stuck in everyday traffic; stories of the Philippines during and after martial law; some stories of the people he encountered; and sometimes with stories about his dreams. These stories clearly depicted the postmodernist celebration of little narrative.

\section{Nonlinear Narrative}

Another feature of postmodernism is the technique of using the nonlinear narrative. This characteristic is very common in literature as one of the literary techniques used in many short stories and novels. It involves the deconstruction of events or the rearrangement of the timeline of the stories. Postmodernist highlights the use of nonlinear narrative in connection with the concept of play in literature including the play of meanings, the play of images, the play of language, and the play of structural forms. Thus, the nonlinearity of a certain work mirrors the notion of play (Whisnant, 2012).

The first scene in the Salamanca (2017) took place at a party in Louisiana where Gaudencio announced that he will return to his wife of eleven days in the Philippines "to settle the matter of his incoherent sexuality and beget a child" (Alfar, 2017, p. 1). After this, the story flashbacked during the time when Gaudencio arrived in Tagbaoran, Palawan, searching for a job in teaching. The narrator relates the story of Gaudencio, Jacinta, and Cesar. The story continues to progress from the meeting of Gaudencio and Jacinta; the flight of Gaudencio and Cesar; the fruitful success of Gaudencio as a writer; the decision of Gaudencio to move to Manilaville, Louisiana, until the narrative reached the party in Louisiana where Gaudencio announced his sudden decision to go back to Manila. Within this timeline, a collection of stories from other characters in the novel is employed inside the main plot presented through the recollection of memories utilizing the nonlinear timeline within a literary text.

After the dramatic narration of these events, the main plot of the story continues to progress in chronological order. It is started when Gaudencio went back to Palawan to convince Jacinta to live with him and have a child. Basically, the whole third part of the novel is presented in a linear timeline although, there is still incorporation of the past related through the storytelling of Jacinta to both of her sons.

The technique of using a nonlinear narrative timeline is present in different forms of literature including novels, short stories, films, and even poems.

Recently, Aiken (2009) discusses the presence of nonlinear narrative techniques in children's literature specifically in picture books. In "The Giant Story", the readers will notice the incorporation of this technique through the use of labels. "The story starts at the end of the plot with the words The End, and ends with Once upon a time" (Aiken, 2009, p. 3).

In contrast to Salamanca (2017), the mode of representation of the nonlinear timelines in children's picture books is explicit due to the presence of the text labels.

Leche (2010) also started with the scene in the past, "by the time Vince arrives at the Philippine Airline departures terminal" (Linmark, 2011, p. 1), recalling the scene on how the 
airport was crowded with balikbayan boxes and how he and his siblings, Jing and Alvin, arrived in Hawaii with this kind of box. Then, the story returned to Manila International Airport, the modern-day Ninoy Aquino International Airport, at the fountain outside the terminal "where vendors sold soft drinks in plastic bags and photographers offered to capture Polaroid moments for seven pesos, the equivalent of one U.S. dollar back then" (Linmark, 2011, p.3). Then the timeline jumped years later during the siblings' get together in Alvin's place where they were reminiscing about the past. The narrative shifted again into the past as the characters delved into their series of memories. These shifts between the siblings' gettogether and the past recurred many times before the narrative turned to a series of Vince's dreams. When he finally woke up, the story appeared in the present time where Vince is currently on the plane bound for Manila. As the story progresses, the shifting from the present time to a specific scene in the past continues to occur.

The narrator uses flashbacks in telling the story, shifting between the events in the past and in the present time of the narrative. However, the flashbacks are presented also in nonlinear structure or non-chronological order making it a bit difficult to follow.

Kurt Vonnegut utilized the technique of nonlinear narrative in his novel Slaughterhouse-Five (1969) which is classified as a postmodern novel. However, the employment of a nonlinear timeline in Slaughterhouse-Five (1969), disrupting the flow of the story, is called temporal distortion where the protagonist Billy Bud is recurrently experiencing the past and the present (Lucy, 1997). Temporal distortion is more complex than merely going backward and forward in time, "removing any sense of coherency typically established by chronological order" (Kho, 2014, p. 2) and disfiguring the notion of cause-and-effect relations.

In Leche (2011), the narrative shifts from past to present to emphasize Vince's recollection of memories in the Philippines as he ventures to the heat and chaos of Manila after thirteen years of living in Hawaii. The recollections of past events come to Vince when he saw or experienced something in the present that can be associated with his past. Sometimes it is presented through some series shifts of dreams. One will notice the shifting of time in the story because it was marked by a header.

Although these markers are present in the text, not all shifting of narrative have it. Some scenes took the reader some time to realize if it is in the present time of the narrative or in the past. If the scene is in the past, what part of the past - Is it during the time when Vince was still in San Vicente? Is it during his early years in Hawaii? Is it during the SpanishAmerican War, World War I, World War II, or Martial Law? - because as mentioned earlier, flashbacks are also presented in non-chronological order.

\section{Parody}

"Parody is an artistic mode that has been present in the arts for a long time. It has both been widely used by writers and thoroughly analyzed by critics" (Salomon, 2013, p. 69). It is another concept that is not totally new but utilized by postmodernism.

Parody is defined in many dictionaries as an imitation to mock or ridicule but postmodernism employs it in a different manner. According to Linda Hutcheon, as mentioned by Salomon (2013), postmodern parody does not mandatory support the idea of mockery instead it dwells much on the reinvention, rearrangement, and revisitation of the past. Hence in the context of literature, it is the reinvention, rearrangement, and revisitation of the past texts or the canon. The contemporary writers reinterpret the previous literary texts and modify it to create another. The parody is the extension of the parodied work. Postmodern parody or what Hutcheon called the blank parody, like pastiche, highlights the postmodern sentiment that nothing is new in the contemporary world. 
In order for the readers to recognize the presence of parody in a literary text, " he or she must be a very well informed reader. The reader should have background readings as well as a cultural or literary memory so as to identify and decodify the texts superimposed" (Salomon, 2013, p. 71).

Leche (2011) is a parody of Dante's The Divine Comedy (1472), not to mention that the book included an epigraph from Inferno on the first page of the book.

The journey of Vince through the hot, noisy, and irritating city of Manila is actually his descend to the Alighierian concept of hell-his journey through Inferno and Purgatorio. Rather than meeting the people who inhabited the circles of hell, he encountered the other characters in the narrative including Sister Marie, Bino Boca, Kris Aquino, Dante, Lilibeth, Jonas, Burrnadette, and Tita $\mathrm{G}$ instead.

The character of the film director Bino Boca in the novel is actually the parody of Lino Broca, the award-winning director in the Philippines, and Kris Aquino is the parody version of the real Kris Aquino in Philippine showbiz. The author uses the literary technique called allusion with his characters to establish the context of the story.

When Vince attended the famous Santacruzan in Malate, Manila, he rode a taxi from Parañaque and converse with the driver named Dante. Dante ferried him to Malate giving him a free historical lesson about different places in Manila including the Cultural Center of the Philippines (CCP), this is a parody of Charon ferrying Dante across the river, Acheron. Finally, his journey to his hometown in San Vicente is his journey towards Paradiso.

In Perspectives on Postmodernism and the Historical Fiction, Chirobocea (2017) discusses how postmodern novelists fictionalize history. They rewrite the events in history to make it as their own version. The texts that are created through this method fall under the postmodern concept called historiographic metafiction.

Canonical literary texts like The Divine Comedy (1472) that are produced in the past are considered historical. Considering the process of rewriting or retelling history to make it as another version, historiographic metafiction therefore can be considered as a form of parody. Even so, Leche (2011) cannot be considered as historiographic metafiction because the story does not really fictionalize history. The story only utilized the concept of descent to Alighierian hell. It does not use the actual Aligerian hell as the setting of the story. Thus postmodern parody is different from other concepts of parody.

Irony

The postmodern concept of irony is associated with play and black humor. It becomes one of the characteristics of postmodernism even though this concept did not begin with them.

Postmodernism does not utilize mockery, ridicule, or humor in their version of parody but they highlighted it instead in postmodern irony. The incorporation of this characteristic in literature is often treated primarily as humor in a serious context and complex structure. Chaudhary \& Sharma (2011) provided an example of postmodern irony in Donald Barthelme's The School (1974) where the central theme of the story is about the death of plants, animals, and people in the second-grade elementary classroom. It mocks the idea of death because it repeatedly occurs. Thus, death was treated as a normal event in the story.

The post-apocalyptic setting of the Naermyth (2010) makes the story serious; with the humanity ending in the world dominated by Naermyths and the remaining humans struggling to live with terror in the walls of the Ruins protected by the Shepherds. Even with this type of community, irony made its way in fragmented pieces, mixing with the story's seriousness.

Examples of irony found in the text with regards to the whole story's serious subject matter are the names of some Shepherd including Sampaloc, Red Horse, and Mamon. 
Shepherds are the strength of the survivors of the human race because they are the ones who gathered the remaining people in a single community, and they are also the ones who fight the Naermyths along their way to certain missions. All of them have their code name in order for them to avoid the "Naermyth's Rumplestiltskin Anomaly" or the ability to control a person in their own will just by knowing his/her name. The irony is in the meaning of their chosen code names. Sampaloc is a Filipino term for tamarind, a sour fruit that grows from a tree. How could someone characterize this fruit in connection with strength? Another is the name Red Horse. In the Philippines, it is a brand for a beer. One would miss the pun in this part if s/he does not know the context of the object just like in the name Mamon. It is shown through Athena's thoughts: "sometimes it keeps me up at night why that ludicrous woman would choose a spongy Filipino cake as an alias when her company was the vilest thing to taste in civil society" (Francisco, 2010, p. 63).

These names can be regarded as the signs, codes, or objects that are randomly thrown in the postmodern world with regard to playfulness. The idea of playfulness in postmodernism is utilized to disrupt the signs' established meaning (Lucy, 1997). Signs in the postmodern world are randomly used just for the sake of using it. Thus, these codes become ironic because they are being used in a humorous way in the novel's context instead of using them in a serious manner.

Another example of irony is the name of the two diwata who play a big role in the story, Maria Makiling and Maria Sinukuan. As mentioned in the discussion of pastiche, Maria Makiling does not want to be called as such because it is too old-fashioned. She wanted her world to become modern so she called herself "Macky", and called Maria Sinukuan "Sookie". Aside from the variation of their names, the house and lifestyle of Maria Makiling are also coated with irony in the service of pastiche. In the whole story of the novel, the lightest part of the narrative is the main characters' encounter with Maria Makiling starting from the moment they met Arao, Maria Makiling's assistant, to welcome them in their place. She is the one who introduced Maria Makiling to the group. She conversed with the characters in an informal way of speaking afar from how the diwatas speak with the tone of authority which is considered as the formal and traditional form of speaking.

Also, the house of Maria Makiling is a good example of irony because of the way in which the strangeness of it appears in the context but the humor will not be effective if the reader does not know the original story of Maria Makiling's legend. Since there are outside references in the text, the reader will be forced to look at the intertextual frames within the novel to completely understand the story's intended humor.

However, Baranova (2006) reveals that Lithuanian writers utilize the concept of irony through the story's narrator as seen in the novel, Fortress of Sleeping Butterflies. "The selfironic narrator has been gaining ground in recent Lithuanian literature. Such a narrator directs the point of his or her irony primarily at himself/herself." (Baranova, 2006, p 144). Thus, the representation of irony in Lithuanian novel is different from the findings of irony in Philippine novels specifically in Naermyth (2010).

\section{Question of Identity}

Due to the postmodernist focus on plurality and little narrative - negating the unifying force of the grand narrative - the idea of establishing an identity is close to impossible. Hence, postmodernism generally features a highly problematic question.

In literature, the focus of the postmodernist in the idea of questioning the identity is self-identity or the personal identity including the character's nationality, gender, sexuality, etc. They did not dwell much on a larger scale such as national, ethnic, and social identity.

The main conflict in Leche (2011) was Vince's identity. Back in Hawaii, he was very sure that he is a Filipino even if he spends more than half of his life living on that island. It is 


\section{English}

only when he came back to the Philippines pushed him to question the authenticity of his identity as a Filipino.

The question of identity is the recurring question in the novel since most of the scenes in Vince's journey often remind him of his identity. One of these scenes is when he appeared on Kris Aquino's show on television where Kris and Sister Marie interviewed Vince about his experience going back to the Philippines for the first time until they arrived at the question of Vince's identity, "Do you identify more as Asian American or Fil-Am?". Vince answered, "Neither" and continued, "Filipino" but Kris insisted, "Cannot be. You just said you've lived most of your life in America". Kris and Sister Marie even emphasized that he is not a Filipino because he cannot speak the Filipino language, and he is not even willing to live in the Philippines for the rest of his life. After this event, Vince has been doubtful of his identity causing the question of his identity to recur and it has gotten worse when he encountered Jonas during his tour in Fort Santiago. Jonas just made Vince's insecurity worse. Unlike him, Vince thought, Jonas grew up in the Philippines, he spoke the language of a Filipino, he lived and continue living in the Filipino way, and he even memorized the history of his own country. Vince felt so little that he does not even have a plan to return to the Philippines soon enough if it was not because of his prize in Mister Pogi.

In Naermyth (2010) on the other hand, Athena, being a Shepherd, is contented with her life. She does not even want to talk about her past life before the war between the Naermyths and the humans occurred. She was so satisfied with the truths that surround her without knowing that what she knew about her life were actually lies. The story established in the beginning that one of the main problems in the story is the real identity of Dorian who is believed to be a Naermyth after Athena had seen the sudden appearance of his wings. Athena, alongside River, was committed to the task of knowing the origins of Dorian including what kind of Naermyth he is. In helping Dorian, as far as Athena is learning about the identity of Dorian, she is also unknowingly learning about her real identity.

\section{Issue of Subjectivity}

Since postmodernism problematizes the notion of identity, it can be connected to the issue of subjectivity or the question of the self or the "I" where the character is unsure of his/her experiences, state of mind, as well as his/her identity.

The issue of subjectivity will be noticed in a literary text if the character is explicitly questioning him/herself about his/her consciousness, experiences, and identity. The character is trying to find answers to his/her own questions and that is also explicitly narrated in the narrative. Thus, the text is actually posing the question of oneself.

Am I a Filipino? - Vince's question problematized his identity through this question. Leche (2011) displays the question of revealing the identity of oneself. "Am I a Filipino?" is like asking the question, "Who am I?". It also shows how one reality is different from the other - the reality of Vince and the reality of Jonas. There is a presentation of different realities and truths in the novel that are co-existing at the same time. Since one was being exposed to the truth of the other, he is asking the question "Who am I?" but unknowingly he was trapped to the question of "Who was I?" as he ventured to his life from the past trying to justify his present identity.

In the study of Montealegre (2008), she discusses how the issue of subjectivity is dealt with and problematized, however it is in the context of a movie. In The Matrix, the protagonist Thomas Anderson/Neo played by Keanu Reeves, asks the question, "Where am I?" which directly emphasizes the question of locating oneself. Neo is trying to search for answers to that question and the other questions too, "Who was I? Today's self, bewildered, yesterday's forgotten; tomorrow's unpredictable?". Like Vince, Neo also asks these questions when he was being exposed to a different version of reality. It is when Morpheus made him 
choose between the red pill and the blue pill. The former will show him the reality and the latter will take him back to his life as a programmer. He picked the red pill and he was brought to Zion, the last safe place in the real world. There, he learned that the Matrix is just a simulation of the real world.

The protagonist of both stories is trapped in the idea of the self, presence, and reality. Thus they question themselves about it explicitly.

\section{Magic Realism}

One of the common techniques of postmodernism is magic realism. It is a technique which gained popularity among the Latin American writers like Gabriel García Márquez. It can also be considered as a genre. Magic realism is a kind of storytelling that involves supernatural elements that were treated as ordinary things in the context of the narrative. According to Chaudhary and Sharma (2011), the literary works with the technique of postmodernism are marked by "the use of still, sharply defined, smoothly painted images of figures and objects depicted in a surrealistic manner".

Salamanca (2017) is composed of sorcery, magic, and fantasy. Hence the title, Salamanca. Some of the events in the narrative were caused by supernatural phenomena including the stories about Jacinta and her glasshouse.

All the residents of Tagbaoran, Palawan can tell the story of how the walls of Jacinta's house turned into a transparent glass to any person who will visit the secluded town. It is a very popular story among the inhabitants of the town because of its connection to magic.

Although in reality, it is something that is not true, the characters in the novel live with this kind of truth. They believe that the unearthly beauty of Jacinta is a curse so they stop giving birth to any child after her twelfth birthday. It is the same house that magically disappeared during the endless downpour of rain that caused the flight of Gaudencio, Jacinta, Mrs. Brown, Cesar, and Shiro that ended with a momentary crash. When Cesar accompanied Jacinta to return to her transparent glasshouse, it was already gone without any trace of existence except for the large hole in the area where it was once stood.

After Gaudencio left Jacinta and went to Manila together with Cesar Abalos, the unearthly beauty of Jacinta was diminished causing the number of childbirth in Tagbaoran to increase but even after this, the supernatural events in town continue to occur. One of these events is the visions of Jacinta about the fate of Carlito who will die from drowning in the sea.

In order to avoid Carlito's fate, Jacinta tried her best not to expose him to a large amount of water. As a result, Carlito developed a fear of water or hydrophobia and because of this, there came a time when Carlito does not even want to drink a glass of water. When all the people in the Abalos household started to panic, only Jacinta remained calm saying that he will drink if he was thirsty. Until one day, Carlito went missing. It is the time when Carlito's aunt, Gilberta, was thinking if this has something to do with the duende's revenge after she kicked the mound with all her might when she was a child. Her grandmother said on her deathbed that they never forgot.

All the people in the Abalos household went to search for Carlito especially Jacinta who assumed the role of Carlito's mother only to find out that he was near the ocean. That day was the fulfillment of his fate, the visions of Jacinta. He stepped off the cliff, surrendering his body to the vast of water in the ocean. He was pronounced dead but resurrected after his grandmother performed a ritual of some sort by offering some of Carlito's possession on the water. "The death of Carlito Abalos and his subsequent rebirth under his original name Carlo Abalos marked the beginning of full decade's worth of unbridled happiness and prosperity in Tagbaoran [...]" (Alfar, 2017, p. 89). 
The success of Tagbaoran continues to grow every day, the bountiful life in that town continues to flourish until the tragic event where the house of Mrs. Brown was consumed by fire.

Soon after this accident, Gaudencio returned to Tagbaoran asking Jacinta to be the mother of his child. Together, they went to Manila and started a new life. They bear three sons and lost the two, their only living son entered married life and has seven children. Gaudencio and Jacinta live together in Manila, they never got a chance to visit Tagbaoran because of too much work both in Gaudencio's workplace and in their household. The magical story of Jacinta's glasshouse during her youth was told to her sons and grandchildren by herself. They even asked her if it is true because they never experienced something magical with Jacinta during the whole time that they are living with her, not until her death.

The presence of magic realism in the novel makes it unique and interesting at the same time. Magic realism is another characteristic utilized by postmodernism to emphasize the blurring distinction between reality and fiction.

The Association of the Postmodern Characteristics with the Overall Meaning of the Novels

Postmodernism, upon drawing the new literary sensibility, elevated the pluralistic interpretation through the celebration of little narratives which is one of the unifying forces of the characteristics of postmodern literature. However, it cannot easily determine the exact scope of its characteristics because it did not concede with a totalizing force which also mirrors the plurality in nature of postmodernism.

Even without a totalizing subject, postmodern characteristics may also be associated with the overall meaning of a literary work as they are still interested in the representation of meaning to understand the contemporary world

\section{Salamanca (2017)}

The initial pages of the novel were so magical. The exceptional story of Jacinta Cordova's unearthly beauty that transformed the walls of her house into fine glasses echoed throughout the town of Tagbaoran in Palawan. This story reached the ears of Gaudencio Rivera upon looking for a possible job in that town. He was successful in ignoring Jacinta's story not until he accidentally discovered the glasshouse, saw the woman, and fell in love with her the moment their eyes met.

The appearance of pastiche in the novel supported the use of magic realism in the text. These two postmodern features are responsible for the supernatural events that occurred in the novel including the transformation of the glasshouse; the uncontrolled attraction to Jacinta upon seeing her as experienced by Gaudencio, Cesar, and even Mrs. Brown; the vanishing of the glasshouse together with Apolinaria leaving no trace of existence; the diminishing of Jacinta's unearthly beauty upon Gaudencio's leaving; the visions of Jacinta about Carlito Abalos' death in the ocean; the resurrection of Carlito Abalos as Carlo Abalos after his death that was anticipated by Jacinta; and finally the transformation again of the walls into glasses upon Jacinta's death. These two characteristics barely affect the meaning of the story. One may notice in the last few pages of the book that Jacinta was telling her story when she was still in Palawan surrounded by magic to her sons. She was remembering every event in her past including her vanished aunt, Apolinaria Vergara, but in one of his letters to Mina, she is asking herself if all of it was true.

These are the stories from the beginning of the novel incorporated with pastiche and magic realism that made the events worth remembering. A mundane event that every day can occur in someone's life or what the realist called regularities may have a lesser impact on someone's memory compared to the things that occurred with the presence of magic. It is 
because people are already accustomed to experiencing the same events in their entire life. The events in the narrative associated with pastiche and magic realism are the stories that the people continue to tell as if they are experiencing it all over again.

The incorporation of the nonlinear narrative also touches the meaning of the story especially the revisiting of the past through flashbacks, recollections, and memories. This narrative technique helps the story to establish its characters' attributes to remember the stories in their past. The readers will initially notice it at the beginning of the novel where Gaudencio is recalling what happened in Palawan a few years ago. They will also notice it in the development of the plot where their past stories are being revealed especially in the second part of the book ("Men, Women, and Other Assorted Fictions").

The inclusion of little narratives from the other characters in the story that acted as subplots of the main narrative also helps in achieving the concept of remembering. Every character in the novel has their own stories that they remembered very clearly even if it took place a long time ago.

When events became memories, they became treasures. Every small story from Tagbaoran was treated like a treasure including those that are incorporated with magic.

Salamanca (2017) is a novel with multiple subjects. These include sorcery, love, lust, literature, friendship, family, and the Filipino nation but the meaning of the story lies within a person's memory. The incorporation of pastiche, magic realism, little narratives, and nonlinear narrative technique barely help to achieve the theme of the story that everyone has the possibility of forgetting what happened in their entire life. Even if a person is not sure if that story actually happened because it felt surreal, as long as s/he remembered it, there is proof that it really happened.

\section{Leche (2011)}

The novel generally revolves around the epic journey of Vince in the busy street of Manila upon returning to the Philippines after thirteen years of living in Hawaii. Along the way, he encountered a lot of things, persons, and events that made him feel that his Filipino identity was being invalidated right in his birthplace.

One of the events that made him doubt his identity as a Filipino is during his interview as a guest in PM Talking with Yours Truly, a talk show hosted by the country's first daughter named Kris. He was being interrogated with questions that he did not expect to cause some sort of devastation within himself. He was first asked why did it take so long for him to come back to the Philippines. He answered that he did not feel the need to come back because there are so many Filipinos in Hawaii. They even have a mini-Manila, mini-Ilocos, and mini-Davao resembling the actual places in the Philippines. He did not feel the need to come back because he somehow feels at home inside a Filipino community in Hawaii. Kris and Sister Marie did not agree with him insisting that it is better to feel at home in the Philippines because it is the place where the "authentic" version of the places they have in Hawaii lies. Kris also asked Vince about self-identification - Is he an Asian, American, or Fil-Am? - only to reinforce to him that he is not a Filipino because he spent most of his life outside the country. Kris and Sister Marie even pointed out his inability to speak Tagalog and his unwillingness to give up his U.S. citizenship. Vince insistently identified himself as a Filipino and continuously insisting that their definition of being a Filipino is "too narrow, too specific, and too literal" (Linmark, 2011, p. 233). He also put up the argument that once a Filipino at heart, always a Filipino in the heart, making Kris unsure about the things she said earlier.

Although the story is basically about Vince, the narrative itself did not solely focus on him and his identity but the identity of the Filipinos as a whole. Vince is only a representation 


\section{English}

of the fragmented identity of Filipinos which was being highlighted by the present postmodern characteristics in the novel.

The multiple elements combined together as represented by pastiche helped the narrative in establishing the plurality of the Filipino identity. These elements are all signs containing pieces of information about the Filipinos and the Philippines. One of it is the appearance of lists labeled as Tourist Tips in the book containing information about Filipino lifestyles, ideas, and sentiments. These lists can be true to some but not to all. Some things that are included in the series of Tourist Tips are the following: 1) Filipinos have many names. First name, middle name, last name, plus a million colorful nicknames - Pochay, Bebot, Pinky, Baby, Buboy, Bobot, Chichay, Dimpy; 2) Filipinos are marathon talkers - on the phone; in movie houses; with food in their mouths; during a church sermon, senate hearing, or academic lecture; when committing acts of crime or passion; and while sleeping; and 3) Filipinos are obsessive-compulsive when it comes to personal hygiene. They shower twice, sometimes three, four, five times a day.

Another evidence of pastiche that helps in building up the meaning of the novel is the excerpts from the Decolonization for Beginners: A Filipino Glossary written by a fictional professor Bonifacio Dumpit. This includes Filipino words that are commonly used in the country.

Aside from pastiche, little narratives with the incorporation of the nonlinear narrative technique are also associated with the meaning of Leche (2011) as they are used to depict the fragmented stories about the Philippines and the Filipinos. Through the use of the nonlinear narrative technique, the small stories formed a perfect collage of events describing the fragmented identity of Filipinos.

Lastly, the presence of the question of identity and the issue of subjectivity in Leche (2011) completed the list of postmodern characteristics that are associated with the meaning of the novel. In fact, it is Vince's question of identity that highlights the theme of the story with the question of subjectivity - the "I" - "Who was I?" and "What is my identity?". How the postmodernist problematizes presence and identity is clearly shown in the novel.

The novel, Leche (2011), constructed with postmodern characteristics such as pastiche, little narratives, nonlinear narrative, the question of identity, and the issue of subjectivity draws the readers to the idea that the identity of the Filipinos is extremely fragmented.

\section{Naermyth (2010)}

Filipinos during their childhood years have heard a lot of stories about strange creatures usually from their grandparents. These are the mythical creatures that are being passed on from generation to generation. In the novel, they were claimed to be an actual living creatures who waged war against human beings. The milieu of the story is postapocalyptic - five years after the war between Naermyths and humans - that was set in the Philippines with the few remaining survivors gathered by the Shepherds in the hope to still preserve the existence of humanity.

Athena or Aegis, her Shepherd's code name, struggled to fight numerous kinds of Naermyths in the Philippines as well as in other countries. She was so dedicated to every mission that was assigned to her, not until she rescued Dorian from duwende captivity. After learning that Dorian is one of the Naermyths, Athena was determined to help Dorian to find his nature and the answer to their mysterious connection because neither one of them knows what kind of Naermyth he is. She hides it from her family, to her fellow Shepherds, and to all the people in the Ruins. After Athena found out that Dorian is an angel of some sort called Wing Wight and learned that Dorian has another sibling which is a Shepherd in her Herd, she 
filled her thoughts about rationalizing who can be Dorian's sibling among her brothers without realizing the possibility that she can be one among the choices.

The incorporation of postmodern sensibilities in the novel helps in building the meaning of the story. Pastiche helps the novel to have different layers of the world by combining the post-apocalyptic world, the mythical world, and the modern world. The perfect example of it is the house of Maria Makiling in the post-apocalyptic world. The house made out of wood is decorated with modern materials inside. The appearance of the house outside conceals what is on the inside making two different world layers. One cannot see the other world unless s/he will enter the house. The different layers of the world also resemble the different layers of truth in the story.

Other than pastiche, the intertextual feature of Naermyth (2010) helps the story to conceal the layers of truth just as how the tikbalang was being portrayed as the Philippine counterpart of centaurs when in fact it is not even a half horse-half human entity, to begin with. Although the novel claimed that myths were never myths in the first place, other myths still remained as myths. Also, some parts of a myth are not totally true because their real meaning was lost in the process of translation.

Moreover, the irony behind the name of the head of the Shepherds named Mamon, initially described as a Filipino sponge cake, is another factor that helps to achieve the theme. Mamon was later revealed as "a derivative of Mammon, the demon of wealth and greedy pursuit" (Franciso, 2010, p. 175). The irony helps to hide the true nature of the character itself by making a humorous account out of a serious concept.

Finally, the incorporation of the postmodern issue of questioning the identity also helps to achieve the novels meaning in an unexpected way. The question of identity in the story comes in two separate stories in the past intertwined with the present events in the novel. It was clearly established that Athena was helping Dorian to track down his identity after finding out that he is one of the Naermyths. Although it was one of the issues in the story, Athena ended up discovering things about herself more than what she had discovered about Dorian. The past events that were slowly revealed through the progression of the narrative help the strange connection of Athena with Dorian made sense. Dorian's search for identity hides the real revelation of the narrative which is the real identity of Athena-the protagonist of the story.

Naermyth (2010) is a tale about survival that is carefully crafted with the richness of myths and culture of the Philippines. The postmodernist tendency to often modify the mythical accounts to blend in the contemporary setting was seen in the novel along with some postmodern characteristics that can be associated with its meaning. Pastiche, intertextuality, irony, along with the question of identity - by concealing the other world, the other truth, the other meaning, and the other revelation - helped to achieve the theme of the story. It basically tells the readers that things were not actually what they appear to be at an initial glance. One must dig deep and see through the thin sheet to find the actual substance that is concealed.

\section{CONCLUSION}

The characteristics of postmodernism are identified in the selected Philippine contemporary novels in English by means of applying the concepts of postmodernism discussed in Niall Lucy's Postmodern Literary Theory: An Introduction (1997). They are the following:1) Pastiche is seen in Salamanca (2017), Leche (2011), and Naermyth (2010); 2) intertextuality is exhibited in Naermyth (2010); 3) little narratives are included in Salamanca (2017), and Leche (2011); 4) the technique of using nonlinear narratives is presented in Salamanca (2017), and Leche (2011); 5) parody is utilized in Leche (2011); 6) irony is used 


\section{English}

in Naermyth (2010); 7) the question of identity is displayed in Leche (2011), and Naermyth (2010); 8) the issue of subjectivity is seen in Leche (2011); and 9) magic realism is utilized in Salamanca (2017).

Pastiche is present in the selected Philippine novel's structure creating a literary collage by including excerpts from a fictional glossary and literary pieces, letters, laboratory report, list of tourist tips, postcards, script, and song lyrics in prose. This postmodern characteristic is also shown through the incorporation of historical events and magical objects within the narrative. Also, it was seen by means of mixing modern objects, furniture, and design with the old structure of the house and the incorporation of the old styles and concepts in the text.

The inclusion of mythical creatures portrayed as real beings with reference to the myths and legends of the Philippines highlights the intertextual frames of Naermyth (2010).

The collection of stories seen in Salamanca (2017) and Leche (2010) is evidence of the postmodern celebration of little narratives.

Salamanca (2017) and Leche (2011) use the nonlinear narrative technique using flashbacks in telling the story to playfully disrupt the chronological arrangement of events.

Leche (2011) is a parody of Dante's The Divine Comedy (1472) which is an example of intertextuality.

The use of irony is presented through Filipino humor involving the things that can only be understood if one was immersed in the Philippine cultural context.

The concept of searching for identity is seen in Naermyth (2010) and was highly problematized in Leche (2011).

The issue of subjectivity is dealt with in Leche (2011) by posing the question of identity as a representation of the question of the self or the "I".

The technique of using magic realism is employed in Salamanca (2017) creating objects that are often imaginary that erase the boundary between realistic and fantastic narrative truths.

The meaning of the novels is more emphasized through the association of the postmodern characteristics present in them.

Other characteristics that are not found in the novels are the following: the absence of closure, hyperreality, metafiction, simulacra, heterotopia, high tech paranoia, multivalence, hybridity, nepantilism, satire, and grotesque.

In light of these findings, postmodern characteristics are indeed present in the selected Philippine contemporary novels and they are suited for postmodern reading.

The postmodern sensibilities exhibited in them are limited to four to six characteristics only; the three novels shared some of the identified characteristics but they differ in the mode of representation. Leche (2011) exhibits the most number of postmodern sensibilities among the three novels, while pastiche is the most common postmodern characteristic that is present among the three novels.

The postmodern characteristics helped each of the narrative to achieve its overall meaning: 1) the postmodern characteristics present in Salamanca (2017) emphasize the importance of memory; 2) in Leche (2011), the identified postmodern characteristics highlight the fragmented identity of the Filipinos; and 3) Naermyth's (2010) postmodern characteristics gives us the idea that things were not actually what they appear to be.

\section{REFERENCES}

Aiken, A., (2009). Postmodernism and Children's Literature. The ICCTE Journal, A Journal of the International Christian Community for Teacher Education 2(2), 1-9. Retrieved 
from: https://www.icctejournal.files.wordpress.com/2013/08/vol2-

2_postmodern_childrens_lit.pdf

Alfar, D., (2017). Salamanca. Mandaluyong City: Anvil Publishing Inc.

Aquino, B. \& Magdalena, F., (n.d.). A Brief History of Filipinos in Hawaii. Retrieved from https://www.hawaii.edu./cps/hawaii-filipinos.html

Ariola, J., (2016). Postmodern Filming of Literature: Sources, Contexts, and Adaptations. Manila: UST Publishing House.

Baranova, J., (2006). Postmodernism in Lithuanian Literature. Athena 3, 135-155. Retrieved from: https://www.lkti.lt/athena/pdf/3/135-155.pdf

Baudrillard, J., (1994). Simulacra and Simulation. USA: University of Michigan Press.

Chirobocea, O., (2017). Perspectives on Postmodernism and the Historical Fiction. Journal of Romanian Literary Studies 10, 233-242. Retrieved from:

https://www.upm.ro/irls/JRLS-10/Rls\%252010\%252031.pdf

Chaudharry \& Sharma, (2011). Common Themes and Techniques of Postmodern Literature of Shakespeare. International Journal of Educational Planning \& Administration 1(2), 189-198. Retrieved from: https://www.ripublication.com/ijepa/ijepav1n2_11.pdf

Francisco, K., (2010). Naermyth. Pasay City: Visprint Inc.

Hamilton, E., (1942). Mythology: Timeless Tales of Gods and Heroes. USA: Warner Books Inc.

Jameson, F., (1991). Postmodernism, or, the Cultural Logic of Late Capitalism. USA: Duke University Press.

Kho, L., (2014). Trauma and Time in Kurt Vonnegut's Slaughterhouse Five. Retrieved from: https://undergraduatelibrary.org/2014/literature/trauma-and-time-kurt-vonnegutsslaughterhouse-five

Linmark, R., (2011). Leche. Canada: Coffee House Press.

Lucy, N., (1997). Postmodern Literary Theory: An Introduction. Massachusetts: Blackwell Publishers Inc.

Lumbera, B., (2015). The Country's Literary Produce for 2000. Retrieved from https://www.ncca.gov.ph/subcommissions/subcommisions-on-the-arts-sca/literaryarts/the-contrys-literary-produce-for-2000/

Montealegre, M., (2008). Standing at Intersections, Traversing Mazes, Embracing Spaces: The Postmodern in Selected Films, Fiction and Poetry. Research Journal, College of Language, Linguistics, and Literature, Philippine Normal University 2(1), 1-20. 
Neziri, A., (2013). Postmodernism Art-Theory: Satire, Irony and Grotesque in Anti-War Novel "Catch-22". 3rd International Conference on Foreign Language Teaching and Applied Linguistics 2(1), 105-110. Retrieved from: https://www.bjes.beder.edu.al/uploads/arch-201602231519551854.pdf

Salomon, V., (2013). The Claim of Postmodern Parody. Textura, 79-74. Retrieved from: https://www/periodicos.ulbra.br/index.php/txra/article/download/

Sedehi, K., (2013). Postmodern Influence in Contemporary Persian Literature. Theory and Practice in Language Studies 3(1), 35-40. Retrieved from: https://www.academypublication.com/issues/past/tpls/vol03/01/06.pdf

Whisnant, C., (2012). Some Common Themes and Ideas within the Field of Postmodern Thought: A Handout for HIS 389. Retrieved from: https://webs.wofford.edu/whisnantcj/his389/postmodernism.pdf

\section{AUTHORS'BIOS}

Diana Joy L. Basada obtained her degree in Bachelor of Arts in Language and Literature at Central Luzon State University (CLSU) in 2018. She is a writer, editor, volunteer for the arts, and intellectual property advocate. Her research interests include Philippine literature, postmodernism, creative writing, and philosophy.

Mark Anthony G. Moyano is an Associate Professor of Literature and Literary Studies in Central Luzon State University. After graduating with a Master of Arts in English from the University of Baguio, Philippines, he received a PhD in Literature from Philippine Normal University. His research interests include postmodernism, postcolonial literary criticism, and sociology of literature. 